\title{
Social Structure and Poverty in the Fishing Community at Pandang-Pandang, Jeneponto in South Sulawesi Province
}

\author{
Maksud Hakim \\ Lecturer of STIE YAPTI, Jeneponto Regency, South Sulawesi, Indonesia \\ maksudhakim@yahoo.com
}

\section{Doi:10.5901/mjss.2016.v7n1s1p188}

\section{Abstract}

This research was conducted in Pandang-pandang, Palajau Village, Arungkeke Sub-district, Jeneponto Regency, South Sulawesi province. This research aims at finding out a scientific information about the social structure as a determinant factor of poverty in fishing communities in Pandang-pandang. This research was a case study research on the basis that this research specifically described clearly the meaning and phenomena that occur. This research also used a qualitative approach to analyze and reconstruct a structure as the cause of poverty in fishing communities of Pandang-pandang. Groups that were selected were the case of group of retainer (Sawi), which are under the management of owners of capital (Parangka'), one group of the fisherman of palanra', one group for fisherman of pappekang, and one group for fisherman of parrengge. It is based on the fundamental assumptions that the three groups considered such cases represent each group of fishermen in the location of the research. The focus of this study is to describe and to find that the social structure is a determinant factor of poverty in fishing communities in Pandang-pandang. The technique of data collection was conducted through interviews and participatory observation. Data analysis was done with the reduction of data focused on the selection, simplification, abstraction and transformation of data from field notes, continued with the presentation of the data and conclusion. Research results explain that there are several causes of poverty at the fishing community in Pandang-pandang. They are the powerful influence of capitalism, inequality systems for results, lack of government policy, the limited marketing system, and uneven income distribution. In addition, it is also influenced by the strong bonds of patron-client and the emergence of the contractual ties. All causes are exploitative in the life of the fishing community.

Keywords: structural, capitalism, patron-client, contractual.

\section{Introduction}

Indonesia is an archipelago that stretches from Sabang to Merauke. The number of recorded Islands is 17,508 . Area of waters is 5.8 million kilometers. The length of the coastline is 81.000 kilometers (BPPT - Wanhankamnas, 1996: 12). It means that on the shores of the sea or the coast, there is a space for a community inhabited by fishermen. One of the coast areas that is long and occupied by some fishermen community are in Jeneponto Regency. One of the existing communities is fishing the community of Pandang-pandang in Arungkeke Sub-district.

Lampe and Salman (Salman, cited in 2006, p. 3) shows the difference income between sawi and penggawa in fishing communities that reaches a ratio of 10: 1 . The gap is followed by the high dependence of the worker groups to groups of financiers. Although efforts have been made in catching the fish from a generation to the next generation, life of sawi or retainer is relatively less developed. They live in a modest home, and the child's education is not much better than his parents do to limited cost. Therefore, after their children finished their primary school, they took them to the sea to help catching fish. Even their children sometimes mated with a relatively younger age with the assumption that their children could be mature and independent quickly. In fact, the level of well-being of their children's life is relatively the same with their parents. Meanwhile, the life of Punggawa or capital owners is relatively better than Sawi. They can send her son to College.

Motorization boat policy and modernization of fishing equipment are directed to improve marine fisheries production fisheries. The result of the increased productivity is expected to improve the quality of life of the fishermen's welfare. However, poverty remains visible in the social structure of the fishing community. They still remain at the bottom of the social ladder in the economy.

Hakim $(2013$, p. 70 ) reveals that poverty is not a problem because poverty is destiny that must be accepted, so there is no effort or steps to solve it. However, it cannot be denied that they also hate poverty. An indication of the quality of the fishing community on poverty Pandang-Pandang in Jeneponto Regency can be seen in the fact that physical. Poor 
fishing village is easily identified from the condition of their residences that is very straightforward. Their home is walled with bamboo matting, roofed with palm leaves, floored with sandy soil. In addition, there are limitations of home furnishings. On other aspects, the degree of dependence is very high. Education is very low, and income is erratic.

Ellis (1984, p. 9) and Tjondronegoro, Soejeno, Hardjono in Asian Development Review (1992, p. 117) revealed that there are at least two kinds of commonly used perspectives. They are structural perspective and cultural perspective. The structural perspective looks at the problem of poverty as the impact of an economic system that prioritizes the accumulation of capital and modern technology products. The structural perspective according to Grace (1987, p. 27) is the view of the radicals who are not acknowledged by the culture of poverty. They emphasize that a failed happens because the structure of impoverishing is working. Marxist theories of capitalism and exploitation and alienation is entirely due to the inability of the parties to the fishermen. The people are poor because they are preserved for the poor. Poverty has functions that support the interests of the dominant group, the ruling elites, or capitalist class. Strohm $(1980$, p. 6) mentions it as entwickelung der unterentwickelung (the development of underdevelopment). Friedman (1992, p. 78) assumes that failed is due to the usurpation of power capabilities to the community (fishermen). The power struggles occur through the expansion of capitalism and practice development in the developing countries at the national and local structures.

According to Friedman (1992, p. 79-92), there are three types of power capability at disadvantaged groups that have been deprived.

1. Social power is in the form of access to land production base, financial resources, information, knowledge, and skills, as well as participation in social organization;

2. Political power is in the form of access to the individual in decision-making, voicing the aspirations, and acting collectively;

3. Psychological resources are in the form of awareness about the self-potential.

In general, this situation is experienced by the fishermen in Pandang-pandang hereditary in their lives. Most residents are seemed to have a magnificent house with all adequate facilities. It would be easy to spot as the residence of the owner of the boat or the owners of capital. The low-income level is the logic if their children have low education. There are many children who must be stopped their formal education before they graduated in elementary school. Moreover, if they pass, they do not continue their study into secondary schools.

Exploitative economic relationships for the owners of capital toward the fisherman and instrumental values (need for achievement) for fishermen in facing the challenge of progress are interlinked. They are functionally related in the fishing community of social structure as the medium. In order to fix this situation, the precision and accuracy of the use of the accurate analysis are required. In reality, both mentalities are not enough if they are only partially analyzed or ignored one of them.

Attitude yanks (exploitative) for owners of actualized through the mechanism of capital income distribution has become the standard rules relating to the joint social action would be inappropriate as a result of the capitalist pragmatism that is solely oriented maximum benefit and a violation of the values of social justice. Based on the phenomenon that has been expressed over the problems of the staple in this study is the social structure as a determinant of poverty in fishing communities of Pandang-Pandang of view.

\subsection{Research Problem}

Based on the phenomenon that has been said above with regard to the problem of poverty can be formulated as follows: "Why does the social structure into the causes of poverty in fishing communities of Pandang-pandang"?

\section{Research Methods}

This type of research is research case studies (case study) on the grounds that this research is specific to describe clearly the meaning or phenomena that occur within the fishing community of Pandang-Pandang. This type of research also uses the paradigm naturalistic approaches (qualitative) to analyze and reconstruct the structurally as the cause of poverty in fishing communities Pandang-Pandang. This research was carried out at the fishing community in Jeneponto Regency Pandang-Pandang, South Sulawesi. The reasoning is that the Regency Jeneponto area, including long beach, and is inhabited by communities of fishermen who make the sea as a source of livelihood in the holds of his life. The group selected case is the case of group retainer-mustard greens, each of which was under the management of a Parangka ' (owners of capital) each for groups of the fishermen palanra 1, ' one group to fishermen pappekang, and one parrengge, fisherman's group. Assuming that these three basic groups of such cases are considered to be representative 
from each group of fishermen who are on site research. The focus throughout this study is to describe and dig and find that the social structure as a determinant of poverty in fishing communities Pandang-Pandang. The technique of data collection was done through interviews and participatory observation. The interview was conducted to explore the structure and meaning to the world of cognitive behavior of the subject researched. The form used is the main interview interviews in-depth interviews, both free and focused. Most of the interviews carried out with the use of local languages. In this way, the informant (parangka', retainer, mustard greens, housewives, religious figures, and community leaders) told me according to the language itself, so that the validity of the data is more secure. This type of interview is also essential to obtain information about the surface and finds out what people think and feel about certain events. (Mulyana, 2001, p. 181). Observation technique used is participating observations or observations contribute that observations made while a bit much participate in the life to the person examined. Researchers involved to follow those who researched in their daily lives, seeing what they were doing, when, with whom, and under what circumstances, and inquire about their actions. The observation is done at once at the time of the interview process underway to gauge how serious or how valid the information provided to compare it with the situation and circumstances of the informant at the time of the interview

Data analysis was done with the reduction of data focused on the selection, simplification and data transformation, abstract rude from the Notes field, followed by the presentation of the data and draw conclusions. Analysis of data from data collection and do more intensive after coming home from the field. All available data were investigated, reduced then abstracted and processed into the conclusion.

The latest tendency in sociology of development that leads to action-oriented approach, which sees poverty as a result of unsuccessful development not only needs to be studied, but as a social evil that needs to be eradicated. Therefore, the study was aimed at understanding, interpreting and analysis on the following matters: "Finding scientific information about the communal structure as a cause of poverty in fishing communities of Pandang-pandang"

\section{Result and Discussion}

\subsection{Causes of Fishermen Poverty are a shareholder to exploit the life of fishing community of Pandang-pandang}

Fall in the price of fish rengge, most Parangka ' strong economy has turned his attention to catching fresh fish in order to meet the demand of the domestic market (Makassar) fish trade between the island and the assessed quite favourable to development on the market economy on the activities of the fishing catch. In addition, effort and sunu snapper fish are also growing rapidly, which involves around 20 units of household enterprises. Community fishermen catch changes (evolution) or transformation toward more advanced and complex (Poensioen, 1969; Maciver and Page, 1962; and Polanyi, 1957). The change relatively quickly, especially after it entered the 20th century, characterized by the influence on the application of technology and the development on the market economy. Berger (1991) shows that simultaneously moves towards the modernization of society.

The results obtained during the field in research information that since the 1970s in any location of almost all the fishermen catch are not in its own right, but rather consumption for sale on the market due to the continued expansion of the capabilities of the domestic market, between the island and exports, rarely found fishing catches are not sold on the market. The more open access to public transportation, availability of storage and processing technology, the increasing population and purchasing power, and the increasing preference for marine fish caused a market demand for capture fisheries increasing results.

In the end, you would have understood, to meet strong market pull, the fishermen catch activity can no longer control the arrest effort traditionally. Capture technologies (such as driving machines, an increase in the size of the ship, and the type of nets), became interested in modernized. Related to that, the elements of capital become an important factor for efforts to increase the ability of the unit arrests.

The development in the use with the type of capture a larger, higher-tech, and greater investment indicate that the activities of fishermen catch their processes towards modernization. It's just that, for example, in catching up with the tool types of rengge and rere, the fishermen demanded more rational in the processing activities of the arrest. The need to use energy more catchers experts (skilled labor), greater capital, the organization is more complex, and more concerned with profit ("commercial") becomes inevitable. This situation reinforces that the pull on the market was the one who pushed the onset of modernization of fishermen catch, rather than induced factors on the fishing communities themselves. With regard to regard to the pull on the market absorbed is a modern, such as the arrest of technology Rengge (ring road nets) and Rere (drag Nets) and a number of back-end equipment (boats with larger size of boat towing machine, Parengge nets, increased engine power, the aircraft carrier wagons preservatives, increased the amount of 
labor and so on). This type of technology is now rated catching most modern local fishing communities, in addition to capture his power far greater than with other types of capture technology also and especially because it can be operated all year round. Unlike on previous technology (papekang and Parengge) which only is seasonal.

Mechanized boats started, first by adding a motor on a sailboat, which later evolved into the boat solely (Masyuri, 1996, p. 6). Mechanization is increasingly intensive and widespread since the early 1970s (Bailey, 1988, p. 30 and Haning, 1988, p. 5-14). One of the important aspects of this modernization is a process of substitution production techniques, traditional ways of turning to the ways that more rational (modern). This change is part of a cultural transformation of society, with all the consequences (Schoorl, 1984, p. 1-6).Because the intended modernization more describes the response to the market, the Group had accessibility against financial institutions, and then it is they who are faster to respond. Of course, it is very easy to understand. Owner fishers' capital (Parangka ') was the first to earn the chance to appear as the dominant economic players ("capitalization technology catching up"). In other words, the fishing workers fewer opportunities to gain profit from the development on the market economy. Thus, on a relative basis can be put forward that the small fishermen, for example, which uses the simple capture tool, fewer direct workers and fishermen could obtain an increase in the guarantee of well-being.

Utilization technology of more recent arrests, of course, closely related to efforts to obtain larger catches. The question that arises then, among others, are the fishermen generally catch since marine resources are jointly owned. In the meantime, theoretical or empirical nature sea resource is limited. Gordon (1986) warned that the arrest of commercial businesses in the ocean will affect fish stocks at sea. Consequently, the greater the commercial catching effort, especially the use of high technology, would further deplete fish stocks at sea.

Symptoms depletion of fish stocks in the sea has started to be felt fishermen, especially in Kecamatan Kasus. As an illustration, it turns out that the perceived space for small fishermen fishing gear simple users increasingly limited. According to both of parengge fishermen especially papekang fishermen, in the last ten years the area was once a narrowing their arrest. Exploitation arrest with rere and gillnets, by the owner of a large motor boat, drain the shallow waters where catch small fishing operations.

The ability of a small portion of fishermen in utilizing the available resources have led to inequality ownership of the means of production and the level of sophistication. Such factors will bring inequality (distortion) revenue among fishermen. Based on existing data, modernization arrest fishermen have managed to increase national fish production (Baliley, Dwiponngo, and Marahuddin, 1987, p. 2-63). Nevertheless the production increase only provide economic benefits to the small proportion of fishermen, the owners of the means of modern production (Parangka'). Most fishermen workers actually remain in the shadows of life of subsistence and poverty.

\subsection{The impact of capitalism in the fishermen lives}

Social inequality caused by inequities in income in the fishing community structure is actually a "cultural heritage" of the Chinese capitalist to Local capitalist (Parangka'). Cultural heritage in question is in the form of the concept of "contractual ties", which is a form of profit-sharing partnership agreement with fishermen require workers to submit all of their catch to the owners of capital to be sold into the market. This phenomenon is relevant to what is meant Poensioen (1969) that the industrialization process personal relationships (patron - client) will be shifted into a contractual relationship characterized. Popkin (1979) refer to as a shift from a relationship that is based on the moral to the relationship based on rationality. Legg (1983) named the shift from multi-complex bond (working relationship that lasted many times that it becomes personal work) to bond simplex (impersonal working relationship with the mechanism of action which refers to the market system).

The question is why the contractual bond in the structure of the fishing community limiting economic opportunities for social class of fishermen so that workers experiencing poverty? It seems necessary understanding of how poverty mechanisms that occur in the social structure of fishing communities. The mechanism in question can be visualized through a system of proportion to the results (the distribution of income) or known to the socio-economic institutions which is a manifestation of contractual ties schematically as follows:

Through the income distribution mechanism can be concluded that in terms of structural low income received by fishermen workers is caused by several things: 1) about the sale price of the catch that is only determined unilaterally by the owners of capital, in this case the owners of capital to act as a buyer; 2) a matter which should be categorized as operating costs are generally in the form of the material, in this case the owners of capital to act as a seller; and 3) about the involvement of certain equipment technology in revenue that is synchronized with the two fishermen workers. Overall the way done by the owner of this capital is in violation of the norms of reciprocity (the result) both against UUBH Fisheries and against Islamic Economic Ethics (Qiradh). The types of offense is what the authors call the exploitation of 
variables, namely the ways in which capital owners seek maximum profit regardless of the legal or illegal.

Until the formal stage, the actual proportion of the results or better known as social institutions as a percentage of the economy is in compliance with the rules of Islamic Economic Ethics (Qiradh). The problem lies in the "how to treat the results", especially in terms of pricing, the use of the operating costs and the inclusion of certain technologies in revenue. It is where sometimes we fooled normatively as if there has been a distribution of income within the social structure, the case in which there are "hidden hands" are not concerned with what is taken, for the pursuit of profit. This situation is called the author generously-civilization, the deviation from social norms and religion through the sharing system in order to gain maximum benefit.

Indeed started happening since Parangka 'mediates between the owners of capital by fishermen workers. Now with the establishment Parangka 'as the owners of capital, pricing is under discretion (to say nothing of power) Parangka' are concerned. Of the 15 retainer along with a number of its workers were interviewed, all stated that the price of gillnet fishing is determined unilaterally by Parangka 'are concerned.

In terms of determining the use of operational costs, it seems that the local capitalists (Parangka') received a strong influence from the banking system which causes them to not want to lose the slightest of efforts; even they remain profitable despite the fishing workers were not getting anything. At least they are trying to reclaim their capital invested (although in time delayed) coupled with the advantages of each material used in the arrest.

When this writer confirm, they (Parangka') generally responded that if how they compare to the way banks, they are actually losing money. Thus it can be perceived that they were actually in the operations referring to the banking system without them realizing that on the other hand they use the system for a completely different outcome to the banking system. It is where the weakness of the system for the results when used by people who mentality bypass (exploitative) on the one hand and those who have a weak instrumental values on the other.

Furthermore, the inclusion of certain equipment technologies (machine towing nets) in revenue (in particular the sub discussion of third case of parengge) really degrading, because in revenue, against a share of $2 x$ part of a cabbage. It means that the technology is equivalent (worth) with 2 people mustard. Though this type of technology is a part of the equipment cannot be separated from other types of technological equipment on fishing unit concerned. It should the type of technology that is intended to be inclusive in a portion of the proceeds (income) of capital owners.

The conclusion that the owners of capital gains obtained through exploitation (the taking) of pricing, usage and operating costs of equipment technology, the three actually based on rationality - greedy, in the form of the pursuit of maximum profit by way claimed the rights of others. Pursuit of profit is justified rationally, but if it was obtained through the taking (exploitation) on the rights of others then act it shows greed.

Relation to the social structure of the retainer-mustard with the presence of rationality - greedy it has shifted the social values that have been much upheld. Social value in question is honesty. In the history of fishing, honesty is the main value (basic) for the formation of the social structure retainer-mustard. A Parangka 'in hiring fishermen fishing workers is believed that the workers handed honestly entire catch to Parangka'. Instead fishermen workers also believe that Parangka 'convey honestly with them about the price and the actual operating costs. But what happened in recent years, both are no longer consistent with the social values. When fishing workers feel overly exploited by capitalists, the workers often fishermen responded by way of the so-called "patte-patte", in the form of taking some part of the catch is illegal to sell to the next in the market or distributed to the entire mustard. It behavior is usually led by the retainer is concerned with the reason that if it is not done then the retainer in question would lose mustard. The social value of said estimated start "decaying" since the beginning of the commercialization of fishing, then be "fragile" at the time of emergence Parangka' intermediaries, and eventually became "destroyed" (priceless longer socially) when Parangka' has become the owners of capital. This is why the structure Parangka'- retainer - more mustard colored by economic considerations (the pursuit of profit alone) rather than social (equity income), particularly from the owners of capital.

\section{Conclusion}

Structural poverty-Glance fishing communities of view due to the strong influence of capitalism, unequal revenue sharing system, the lack of government policies (state), limited marketing system, as well as the uneven distribution of income. It is also influenced by the strong patron-client ties on the one hand and the emergence of contractual ties on the other hand, all of which are exploitative in the life of the fishing community. 


\section{References}

Anonim. (1987). Memacu Masyarakat Berprestasi. Translated by Siswo Suyanto. Jakarta: Intermedia.

Anonim. (1991). Tafsir Sosial atas Realitas. Jakarta: LP3ES.

Bailey, Conner. (1988). The Political Economy of Marine Fisheries Development in Indonesia. In Indonesia, No. 46 (October).

Berger, Peter L., \& Luckmaun, Thomas. (1988). The Social Construction of Reality. New York: Anchor.

Gordon, H.S. (1986). Teori Ekonomi tentang Sumber daya Milik Bersama. In Ir Smith, \& F. Marahuddin (eds), Ekonomi Perikanan: Dari teori Ekonomi ke Pengelolaan Perikanan. Jakarta: PT. Gramedia.

Hakim, Maksud. (2013). Dialektika Komtemporer. Jurnal Sosiologi, 1(2).

Lampe, Nubsi., \& Salman, D. (1996). Laporan Studi Analisis Sosial untuk Program Perencanaan Rehabilitasi dan Pengelolaan Terumbu Karang di Sulawesi Selatan. Ujung Pandang: LIPI-Unhas.

Legg. K. R. (1983). Tuan, Hamba dan Politisi. Sinar Harapan: Jakarta.

Maciver, RM., \& Page, C.H. (1962). Society: An Introduction Analysis. London: MacMillan \& Co.

McClelland, David. C. (1961). The Achieving Society. USA: Van Nostrand.

Mulyana, Deddy. (2001). Metodologi Penelitian Kualitatif: Paradigma Baru IImu Komunikasi dan IImu Sosial Lainnya. Bandung: Remaja Rosdakarya.

Polanyi, K. (1957). The Great Transformation: The Political and economic Origins of Our Time. Boston: Beacon Press.

Ponsioen, J.A. (1969). The Analysis of Social Change Reconsidered: A Sociological Study. The Hague: Mouton Publisher.

Popkin, Samuel. (1979). The Rational Peasant: The Political Economy of Rural Society in Vietnam. California: California University Press.

Schoorl, J.W. (1984). Modernisasi Pengantar Sosiologi Pembangunan Negara-Negera Sedang Berkembang. Jakarta: Gramedia.

Salman. (2006). Tahap Transisi Dalam Transformasi Industrial pada Komunitas Maritim di Sulawesi Selatan. (Dissertation). Bandung: Universitas Padjajaran. 